\title{
An Analysis on the University-level and School-level Rights Allocation Theory in the Governance of Colleges and Universities
}

\author{
Jingbo Feng \\ Northeastern University \\ Shenyang, China 110169
}

\author{
Wanbing Shi \\ Northeastern University \\ Shenyang, China 110169
}

\begin{abstract}
The clarity of power and responsibility is the key factor to determine the efficiency of internal governance. And the advantages and disadvantages of university-level and school-level rights allocation are the basis of the clarity of rights and responsibility. The study expounds the necessity of this research on university-level and school-level rights allocation from the macro and micro levels. It uses the method of literature to sort out the relevant research results at home and abroad. And it mainly includes the relevant concepts of university-level and school-level rights allocation, the university-level and school-level division of rights and responsibility, the objects and contents of university-level and school-level rights allocation and other several aspects. It analyzes the shortcomings of the current research results, and provides the basic basis for the further study of university-level and school-level rights allocation in colleges and universities.
\end{abstract}

Keywords-the governance of colleges and universities; university-level and school-level rights; rights allocation; the status quo of research

\section{INTRODUCTION}

The core of university management is the rights. And it is the decisive factor for the reform and development of colleges and universities. The optimal allocation of university rights is of great value to play the functions of colleges and universities and have a good management. Therefore, it is an important measure to improve the efficiency of colleges and universities by constantly adjusting the internal management system and optimizing the university-level and school-level rights allocation. And it is the key to achieve the effective management of colleges and universities.

\section{THE REFORM OF GOVERNANCE AND THE IMBALANCE} OF RIGHTS ALLOCATION IN COLLEGES AND UNIVERSITIES

From the macro level, the irrationality of the universitylevel and department-level rights allocation leads to the inefficient management and large internal friction. At present, the university-level and school-level rights allocation in colleges and universities in China is mainly to

Fund Project: The research is on the 13th five-year plan of education science in Liaoning Province in 2016. The research is on the Universitylevel and School-level Rights Allocation policies in Colleges and Universities (JG16DB398). move down the general rights. And financial rights, human rights, and major business rights are still concentrated in the universities. The decentralization of rights is not in place. The rights allocation is unreasonable. And it seriously affects the expected effects of the school works. The main reason for this thing is that many universities give many specific matters to the schools. However, there are still some rights (especially financial rights, rights of personnel management and decision-making rights of discipline construction, etc.) concentrated in the universities. And it constrains the enthusiasm of the schools.

From the micro level, it is difficult to stimulate the work enthusiasm of grassroots organizations with the imbalance between the university-level rights allocation and schoollevel rights allocation. Since the implementation of the college system, it has formed a business structure between the departments and the universities. The department has become a physical organization for the university to perform teaching, research and social services. However, many colleges and universities don't deal with the integration of rights and responsibilities, the unification of the centralization and decentralization, and the combination of encourage and control. There are few changes between the schools and the original departments in the organization and structure. And the main change is the name and size. The structure or model of grassroots academic organization in the schools is relatively simple. And most of them are the departments, the research rooms or the research institutes. The institutes belong to the schools in the organizational structure. Also, the members belong to the schools. So it is difficult to form a relatively independent organization of interest groups. And it is difficult to fully express their organization demands. And there is no distinction among the research institutes in universities and the research institutes in schools, the research center and teaching and research office of the departments. Even, there are a lot of scientific research organization without capital, organization and class supervision. The grassroots academic organization can't form the organizational power which affects the rights allocation. It is difficult to make a right claim for status. To a certain extent, it affects the empowerment of the colleges to the schools. 
The core of the university-level and school-level rights allocation is to move down the rights. The foundation is the reconstruction of the organizational system, especially the reconstruction of the organizational system in the schools. In the absence of the sound organizations and institutes, it moves the rights down. And then, the rights will not be in effective supervision, checks and balances. On the university-level and school-level rights allocation, to move down the rights should be carried out with the construction of the organization at the same time. In the absence of effective checks and balances and supervision, it should not move the rights down easily. Therefore, in the universitylevel and school-level rights allocation process, the ways to strengthen the construction of the organization and institutional innovation of the schools are also important questions worth discussing deeply.

\section{RESEARCH STATUS AND DEVELOPMENT OF UNIVERSITY-LEVEL AND SCHOOL-LEVEL RIGHTS ALLOCATION IN COLLEGES AND UNIVERSITIES}

\section{A. Overseas Research Achievements}

1) In Macro level-Research on the essential attribute, distribution and operation of higher education rights: Some foreign scholars use the whole higher education system as the research background. They have studied the distribution and operation of the rights in the higher education system among all levels of organizations and the various interests groups. For example, John van der Graff made a comparative analysis on the structure of the academic rights of colleges and universities in seven countries such as the Federal Republic of Germany, Italy, France, Sweden, the United States, Britain and Japan with organizational sociology, comparative political science and public management and other knowledge. And it summed up four models of the structure of the rights, such as the European model, the British model, the American model and the Japanese model. And it also put forward four analytical perspectives. For example, the analytic hierarchy process, integration analysis, differentiation analysis and benefit analysis. [1] Burton Clark believes that work, beliefs and rights are the three main features of the higher education. He argues that the ways of working expression and work schedules are the first element. And the work in colleges and universities are distributed in two basic crossing institutions, such as the subjects and the schools, the schools and the universities. Faith is the second essential element. It includes the main norms and values of many actors in different departments of the system. The rights are the third basic element. The integration and coordination of various elements and various rights promotes the formation of triangle coordination model of the state power, market and academic authority. [2] John Brugbeck studies the subjects of the rights of colleges and universities. He believes that all kinds of subjects have the desire and opportunities to participate in the management and decision-making of colleges and universities. However, the specific rights allocation shows the characteristics of diversification and imbalance. [3] Michael Shattock studies the constraints of rights allocation in the United States, Britain and Japan. He believes that the political system of the state, inertial behavior pattern formed in the development of colleges and universities, and the mutual reference and imitation among the countries are these three factors contributed to the current rights allocation models of different countries [4]. Robert Berdahl divides university autonomy into substantive autonomy and procedural autonomy. Substantive autonomy refers to the rights that the colleges and universities can decide its own goals and plans in the form of a group-what the academic institution is. Procedural autonomy refers to the rights that the colleges and universities decide its own means to achieve these goals and plans - the ways of the works of the academic institution. [5] This is good for us to understand the constraints and principles of internal management system and the rights allocation in the colleges and universities. And it would have some referential value. Bourne Baum studies the characteristics of operating mechanism of foreign universities. [6]

2) In Microcosmic level-Empirical studies on the rights allocation and operation in specific colleges and universities in different countries: In the past two decades, some foreign scholars have also discussed the structure of internal governance which is closely related to the university-level and school-level rights allocation in different countries. Williams, G. and Blackstone argue that the operation of the organization will be the most effective with the implementation of the real school management in any organization based on a high level of professional skills. The collegiate system is conducive to the promotion of discipline development. It is conducive to the personnel cultivation in thick foundation and wide caliber. It is good for the implementation of the credit management system in colleges and universities. Also, it is conducive to strengthening academic exchanges and rationalizing the administration. [7] Clive Dimmock believes that the university governance are mainly competed by three interest groups such as the students, teachers, school-affected groups in foreign universities. The management process is the core of management. It includes the leadership of the principal and other aspects of the organization, such as the degree of distribution of the leadership, the manners to motivate the faculty, the degree of stimulation, the activity plan, and the ways to make decisions, the ways to communicate with the staff, the solution to the contradictions, and the assessment and development, and so on. [8] Hollinger believes that it generally takes three management methods of the universities, the schools and the departments in colleges and universities in the United States. And it shows the "sharing governance". Then, the academic institutes and administrative organizations perform their own duties. And they supplement each other. [9] 


\section{B. The Status of Domestic Research}

Domestic scholars make relevant researches on the university-level and school-level rights allocation. And the researches can be divided into four themes: the governance of universities, rights allocation, the university-level and school-level and school management. There are 1447 articles on the governance of universities. There are 628 articles on the rights allocation. There are 67 literature on the university-level and school-level management. There are 21 literature on the university-level and school-level institutes.

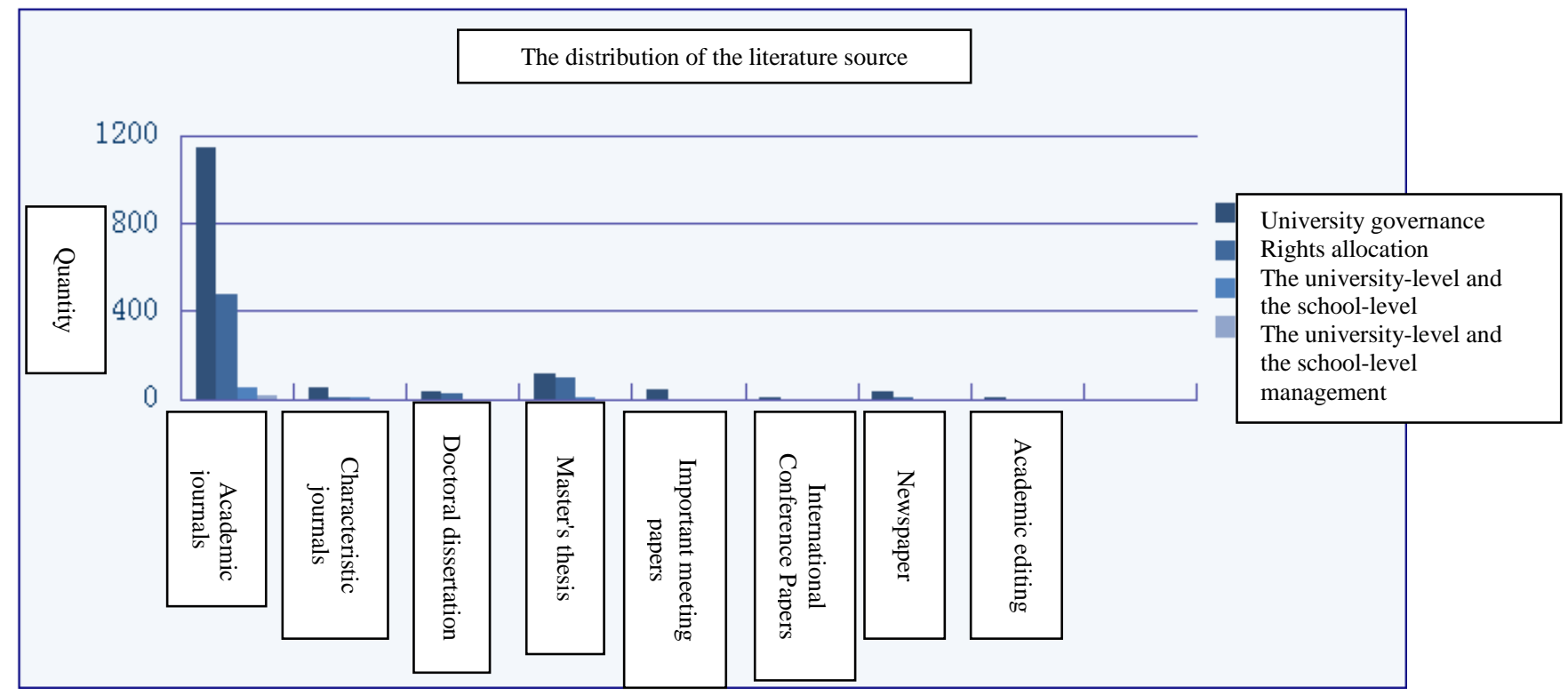

Fig. 1. The distribution of the literature source.

1) Research on the university-level and school-level rights allocation: There are many relevant literature on the university-level and school-level rights allocation in "Fig. 1". For example, Zeng Ling, discussion on the basic functions of universities, schools and departments with the implement of collegiate system; Yu Jianwei, the internal management system of the schools in the collegiate system, the reform of collegiate system and the adjustment of internal rights structure in colleges and universities; Chen Dubin, reflections on the implementation of three-grade management of departments in colleges and universities in China; Liu Jinyi, on the implementation of the secondary management system in colleges and universities; Yuan Zuwang, collegiate system and the reform of longitudinal management system in colleges and universities. It is about 30 articles on this theme. These studies show three characteristics. Firstly, the degree of strength and depth of the research on the rights allocation of universities is inferior to that of the research on other aspects of university rights. Secondly, the research on the rights allocation of universities in Micro-level is inferior to studies on the rights allocation of universities in Macro-level. Thirdly, in the rights allocation of universities and the university-level and school-level rights allocation, the existing researches mostly remain in the principle of allocation, value orientation and other abstraction levels. And the theoretical points and practice path are not clear enough. Fourthly, the existing researches lack specialized, systematic studies on the university-level and school-level rights allocation. These studies are generally distributed in the governance of university, school internal management system, rights distribution of universities and other dimensions.

2) Research on the Concept of the university-level and school-level rights allocation in Colleges and Universities

The rights is the core concept of the researches on the university-level and school-level rights allocation. In the relevant literature, Chinese and foreign scholars have different interpretations of rights. Some scholars regard the rights as a dominant force of subjects of the rights from the perspective of the strength [10]. Some scholars believe that the rights are nothing but the ability or potential of a person in a position to make a decision from the perspective of the ability [11]. Some scholars regard the rights as a mandatory control in the context of a conflict of interest or a conflict of values between individuals or groups from the perspective of control [12]. Some scholars believe that the rights would have influences on others through different means, especially the means of control from the perspective of influence [13]. Some scholars believe that the rights are the legal power to make command, coordination, management, and restraint of the members in specific social organization from the perspective of jurisprudence. [14] Through the comparison on these views, it can be seen that the essence of the rights is the abilities to change, dominate, and control others. And then, the individuals or groups have the others done anything according to their own wills. So the controlling power and influence are the foundation of the rights.

The rights allocation pattern is like that. Some scholars in China have used the theory and method of game theory to 
study the model of the university-level and school-level rights allocation. Tang Xuan has proposed the basic assumptions of the subject of game model of the rights in colleges and universities. On this basis, it makes the comparative analysis on the "strong, weak and weak" rights structure, the "strong, strong and weak" rights structure, the "strong, strong and strong" rights structure. [15] Teng Shitao makes a summary of the existing problems in the universitylevel and school-level management. From the perspectives of the universities and schools, it puts forward the university-level and school-level management program. [16] Chen Yinan and Yang Jinghong make the relocation and decomposition on the university-level and school-level rights and responsibility. On the basis of analyzing the relationship between the interests of the schools and the influencing factors, they put forward the game model of the university-level and school-level rights allocation. [17]

3) Research on the segregation of duties and the university-level and school-level rights and responsibilities

The core of the university-level and school-level rights allocation is the division of the rights and responsibility between the schools and universities. From the content of the current researches, the studies on the types of university rights have formed a consensus. It is generally accepted that the university rights can be divided into four basic types: political rights, executive rights, academic rights and democratic rights. However, there are differences in the principles of the distribution of the rights and value orientations. The mainstream is to control the political rights and administrative rights, and to advocate the academic rights and democratic rights. Actually, it is an important misunderstanding between the theory and the practice. [18]

4) Research on the objects and content of the universitylevel and school-level rights allocation

The research on the objects of the university-level and school-level rights allocation is mainly from three aspects: the allocation of personnel rights, financial rights and transaction rights. From the point of human rights, Sun Jie believes that it is necessary to protect the autonomy of personnel in colleges and universities and to ensure the democratization of personnel management in the macro level. In the micro level, the college should strengthen the construction and improvement of academic organizations. Also, the school should strengthen the supervision of the rights. [19] Zhang Xin believes that the implementation of positions establishment and grading employment are the reallocation and integration of the reform of personnel management system and the innovation of internal resources in colleges and universities. [20] From the point of financial rights and authority, $\mathrm{Li}$ Yong believes that the allocation and management of resources under the university-level and school-level management system should formulate the school charter and clear the university-level and schoollevel management mechanism. [21] Zhang Ying puts forward the solution "the university-level and school-level management, move down the financial rights". [22] $\mathrm{Li}$ Suzhen argues that it is necessary to implement the objectives of the university-level and school-level management, and establish a scientific evaluation mechanism. It should incorporate the performance evaluation into the performance assessment of the office level cadre in the colleges. [23]

The research content of the university-level and schoollevel of rights allocation is mainly carried out from three aspects: decision-making rights, executive rights and supervisory rights. From the point of the decision-making rights, $\mathrm{Yu}$ Yuanchao argues that the implementation of the university-level and school-level management has a higher requirements for the leadership of the management and decision-making level. When the universities really move down the rights, the schools have much rights to control the personnel rights, financial rights and material rights. However, the schools wouldn't have the reform, innovation and progress with the traditional thinking. [24] From the point of the implementation, Huang Hengxue believes that the university-level functional departments in China's university teaching management system focus on the rights. And the middle and bottom management departments lack of autonomy. The constraint of the teaching management rules and regulations are strong. Also, it limits the freedom of teachers and students. [25] Zhu Guangjun thinks that the school management system includes the teaching, researches, students, the hospital affairs and other aspects. And the hospital management system involves the democratic central system, the conference system, the party committee meeting system. [26] Pan Yajing argues that professional director system is the improvement of the university-level and school-level management. The implementation of the professional director system can promote the transition of the university-level and schoollevel management from the model of three-level system to the model of two-level system. And it promotes the transition of the teacher management from the model of static management to model of the dynamic management. [27] Zhou Zhiguo believes that the current implementation of the rights in our colleges and universities is not in place. The gravity of the rights is moved down appropriately. Also, it lacks scientific college assessment system. [28] From the point of supervision, Lv Cixian and Ren Liqing argues that the university-level and school-level management system needs to establish a crossing, all-round, threedimensional, dynamic teaching quality monitoring system in the university-level and school-level teaching environment. And the functional departments and all employees participate in the independent and interrelated teaching quality monitoring system. [29]

\section{THE DEFICIENCIES AND SUGGESTIONS FOR IMPROVEMENT OF THE UNIVERSITY-LEVEL AND SCHOOL- LEVEL RIGHTS ALLOCATION RESEARCH IN THE COLLEGES AND UNIVERSITIES}

\section{A. The Relevant Results on Overseas Research Have Local Adaptability Problems}

Western scholars don't provide an appropriate and basic model of the university-level and school-level rights allocation for China's national conditions. The universitylevel and school-level rights allocation in overseas universities is based on the real conditions of its state and 
social relations, and the accompanying political system, economic system and the tradition of management. Generally, it makes the studies on the university-level and school-level rights allocation within the framework of the university governance, university operation and management system in the border context of the rights relationships between the university and the government. Chinese scholars also make comparative studies on the relevant problems of the university-level and school-level rights allocation in overseas universities from different levels and areas. And it puts forward many inspiration and references. However, these studies are like a map to guide the tourists. And you wouldn't know the specific attractions and streets in this map. If it doesn't systematically describe the specific operation of the university-level and schoollevel rights allocation in foreign schools, it can't really establish the theory and method of the university-level and school-level rights allocation in our country, especially without taking into the consideration of the differences between China's political economy and culture and the foreign political economy and culture.

\section{B. The Research on Basic Theory Is Weak, and Fails to Form a Established Research Paradigm}

The research results mostly lack the basic theoretical research on the university-level and school-level rights allocation. And it hasn't formed the scientific thinking and system practice model of the university-level and schoollevel rights allocation. The value choice and thought design of the university-level and school-level rights allocation are usually constructed on a certain basic theory. It's a theoretical paradigm. And then the university-level and school-level rights allocation is based on these theories. These theories always run through the university-level and school-level rights allocation, support the concept of the university-level and school-level rights allocation, and embodies in the content of the university-level and schoollevel rights allocation. Therefore, the basic theories or theoretical paradigm are the ideological basis of the university-level and school-level rights allocation. And it should be clear in the studies on the university-level and school-level rights allocation in first time. Some scholars at home and abroad have discussed the related issues of the university-level and school-level rights allocation with organizational behaviors, modern leaderships, educational sociology, public governance theory, stakeholder theory and game theory. However, these fragmented theories based on different hypotheses are objectively narrow, lacking the symbolic interaction paradigm and the integration of disciplines or theories. In the higher degree of philosophy, it has made the researches on the university-level and schoollevel rights allocation. And it seems that the theoretical basis of researches is not rich. Philosophy is an activity that illustrates and confirms the meaning of knowledge proposition. The studies on the university-level and schoollevel rights allocation are based on the philosophical basis with the comprehensive characteristics. And then it can make the relevant proposition accurate and define its boundaries and connotations.

\section{Most of the Research Achievements Are too Simple and Abstract, and Operability Is Not Strong}

The current research achievements can't really provide a realistic theoretical foundation for the university-level and school-level rights allocation in our country. Speaking of the conciseness of the current theories, it doesn't make a deep analysis on the types and structures of the university-level and school-level rights allocation, the objects, content and mechanism of the university-level and school-level rights allocation, the conditions of the university-level and schoollevel rights allocation and its creation, and the related management tradition, policy environment, leadership characteristics, management, the nature and characteristics of the matters in addition to the deficiency of the theoretical basis. Research achievements or conclusions have the horizontal increase without longitudinal expansion. Speaking of the abstraction, most of the current researches abstractly put forward the principles and paths of the university-level and school-level rights allocation. And it doesn't systematically explore the dynamic mechanism and operation model of the university-level and school-level rights allocation in depth. The dynamic mechanism of the university-level and school-level rights allocation refers to the components of the university-level and school-level rights allocation and its operation mode with dynamic, relevance, chain, long-term and other characteristics. It makes the analysis and explanation on the dynamic mechanism of the university-level and school-level rights allocation from the perspective of practical logic. The university-level and school-level rights allocation is a practical activity. And then, it makes the analysis on the mechanism of the university-level and school-level rights allocation. And it makes the evaluation on the problems in the university-level and school-level rights allocation and its solutions. Then, it would provide theoretical support for the improvement of the university-level and school-level rights allocation in our country. The current studies haven't proposed a operation model of the university-level and school-level rights allocation.

\section{CONCLUSION}

There is no doubt that the reform of the internal governance structure of the university is the foundation and basis of the establishment of the modern university system. And the university-level and school-level rights allocation is the key to the internal governance of the universities and colleges. Many experts and scholars at home and abroad have made positive and useful exploration on the rights of the university and its optimal allocation and other aspects. And they have made good policy against the disadvantages of governance. And they have little interest on the university-level and school-level rights allocation. It is the main theoretical construction and practice. And the existing literature is mainly on the subject of the rights. It is cited by the classics and organizations. It would make subjective assumptions easily. And the operation isn't strong, comprehensive and deep. The rights allocation of the university must follow the basic theoretical paradigm. It has made the overall co-ordination and system planning over the main body, the object and the content of the rights. At the 
same time, in the concepts of restructuring organizations, the improvement of mechanism, the innovation of system and cultural construction, it can create conditions and protection to achieve the functions of the university healthily.

\section{REFERENCES}

[1] [Canada] John van der Graff. Translated by Wang Chengxu. Academic rights - The comparison on management system of higher education in seven countries [M]. Hangzhou: Zhejiang Education Press, 2001

[2] [US] Burton Clark. Translated by Wang Chengxu. Higher education system - transnational researches of academic organizations [M]. Hangzhou: Hangzhou University Press, 1994.

[3] [US] John S. Brugbeck. Translated by Wang Chengxu. Philosophy of higher education [M]. Hangzhou: Zhejiang Education Press, 2002.

[4] Michael Shattock. Re-Balancing Modern Concepts of University Governance[J]. Higher Education Quarterly, 2002(3)

[5] Robert Berdahl. Co-ordinating Structures: The U GC and US State Co-ordinating Agencies. In Shattock[A], Mi-chael, The Structure and Governance of Higher Education. Society for Research into Higher Education,1983. 69.

[6] [US] Robert Burnham. Translated by Bie Dunrong. The operation model of universities - The control system between university organization and the leadership [M]. Qingdao: Ocean University of China Press, 2003.

[7] Williams G, Blackstone T. Response to Adversity, Society for Research into Higher Dducation[J]. Guildford, (1983).94

[8] Clive Dimmock. Comparing Educational Organizations.Comparative Education Research: Approaches and Methods[J].Hong Kong:Springer.2007.288.

[9] Hollinger. David A. Faculty governance, the University of California. and the future of academe[J]. Academe May /Jun, 2001., 87(3): 30.

[10] Dong Yunhu. On the concept of rights [J]. Human Rights, 2006 (2): 28.

[11] [US] Thomas Dey. The one who is in charge of the United States [M]. Beijing: World Knowledge Press, 1985: 9.

[12] [US] Kurt W. Barker. Social Psychology [M]. Nankai University Press, 1984: 19

[13] [US] Robert Dahl. The analysis on modern policy [M]. Shanghai Translation Press, 1987: 4.

[14] Xu Binlong. The concept of rights in the field of jurisprudence [J]. Party and government forum, 2008 (09): 41.

[15] Tang Xuan. Research on the mechanism of integration of the rights in Chinese public universities based on governance [D]. Wuhan: Wuhan University of Technology, 2007.

[16] Teng Shitao. The university-level and school-level management under the perspective of game theory [J]. Shandong Social Sciences, 2015 (5).

[17] Chen Yiman, Yang Jinghong. Research on the game relationship of university interest based on institutional system $[\mathrm{J}]$. Journal of Southwest Petroleum University (Social Science Edition), 2009 (1).

[18] Sun Mitao. The unity of opposites of academic freedom and control A re - examination of the nature of academic freedom in the university [J]. Education Research. 2011 (6).

[19] Sun Jie. Research on the decentralization of the university-level and the school-level personnel rights--- Taking the implementation of university teacher appointment system in Huazhong University of Science and Technology as an Example [D] ( The master's thesis of Huazhong university of science and technology )

[20] Zhang Xin. Study on problems of post - setting and hierarchical employment under the university-level and the school-level management system in Colleges and Universities [J]. China Human Resources Development, 2010 (02): 102-105.
[21] Li Yong. The resource allocation and management under the university-level and the school-level management system in universities and colleges [J]. Friends of Accounting, 2012 (12): 109110.

[22] Zhang Ying. To deepen the reform of the budget allocation model of the university-level and the school-level funds [J]. Friends of Accounting, 2011 (03): 89-91.

[23] Li Suzhen. Study on the financial management mode of colleges and universities under the university-level and the school-level management system [J]. Financial News, 2011 (10): 156-157.

[24] Yu Yuanchao, Zhou Li. Problems and countermeasures in the university-level and the school-level management in universities and colleges [J]. China Adult Education, 2008 (21): 40-41.

[25] Huang Hengxue. A study on the university-level and the school-level teaching management of colleges and universities under the modern university system [D]. Zhengzhou: Zhongyuan Institute of Technology, 2012: 18-19.

[26] Zhu Guangjun. The construction and practice of the management system and operation mechanism of the secondary schools [J]. Journal of Chongqing University of Science and Technology, 2013 (11): 166.

[27] Pan Yajing. The implementation of the professional director system under the university-level and the school-level management system [J]. Education Review, 2007 (04): 35.

[28] Zhou Zhiguo. Study on the university-level and the school-level management system of local colleges and universities [J]. Education and Career, 2014 (01).

[29] Lv Ci Xian, Ren Liqing. To establish and improve the universitylevel and the school-level teaching quality monitoring system $[\mathrm{J}]$. Jiangsu Higher Education, 2012 (01). 